\title{
Impact of different artificial light intensities on some reproductive, productive performance aspects and blood picture of male quail
}

\author{
H.N. Maty ${ }^{\circledR}$, S.M. Ahmed ${ }^{\circledR}$ and A.A. Hassan ${ }^{\circledR}$ \\ Department of Physiology, Biochemistry and Pharmacology, College of Veterinary Medicine, University of Mosul, Mosul, \\ Iraq
}

Article information

Article history:

Received July 24, 2020

Accepted August 30, 2020

Available online October 1, 2021

\section{Keywords: \\ Spermatogenesis \\ Blood picture \\ Growth \\ Quail}

\section{Correspondence:}

H.N. Maty

hemyatem@yahoo.com

\begin{abstract}
This experiment was designed to determine the influence of various white light intensities on spermatogenesis, hematology and growth performance of male quail. A total of 80 birds of one day aged had been assigned to four equal groups: G1 control group was kept under natural light program $12 \mathrm{~h}$ light:12h dark. G2, G3, G4 were exposed to artificial white light emitting diodes at $0.6,45$ and 25 Lux for 5 hours daily for 8 weeks starting at 14 days of age. The result showed that the application of Lux $0.6,45$ and 25 caused a significant increase in heart weight relative to control. Lux 0.6 led to decrease in total body weight, left testis weight and foam weight. The result revealed that exposure to 0.6 Lux caused significant decrease in sperm count and live sperm percentage and increase in dead sperm percentage. Program of 25 Lux generated a significant increase in RBC counts compared to 0.6 Lux. Exposure to 45 Lux and 25 Lux triggers a significant increase in PCV and hemoglobin concentrations. Exposures to 0.6 Lux and 25 Lux resulted in a significant increase in mean corpuscular hemoglobin concentration, while apply to program 0.6 Lux cause increase in stress index. The best feed conversion ratio was detected in normal daylight, 0.6 Lux and 25 Lux respectively. In conclusion, exposure of male quails to different intensities of white LED bulb had an effect on the some physiological and reproductive parameters.
\end{abstract}

DOI: 10.33899/ijvs.2020.127774.1526, (CAuthors, 2021, College of Veterinary Medicine, University of Mosul.

This is an open access article under the CC BY 4.0 license (http://creativecommons.org/licenses/by/4.0/).

\section{Introduction}

Many physiological functions are affected by light, which is a vital part of the physical environment (1). Light could be affected quail development, physiological efficiency, reproduction and behavior (2). Light is consisting of three different aspects: intensity, photoperiod (duration) and wavelength (color), so both photoperiod and light intensity are essential environmental factors, light intensity, color and photoperiodic regime will influence the functioning of broiler chickens (3). Light Emitting Diode (LED) bulbs help in providing lower energy consumption and long lifespan than standard incandescent and fluorescent lamps and could be an effective lighting choice throughout the poultry industry (4). In the poultry industry, artificial lighting was widely used to improve production and reproductive performance (5). Natural or artificial light has been one of the environment factors which affect the growth, reproduction and welfare of poultry by modulating different bird behaviors and physiological functions (6). Poultry has vision-sensitive retinal photoreceptors, while non-visual (extra-retinal) photoreceptors are able to detect and adapting photoperiods to the environment (7). Light stimulate the GnRH pathway directly which increases the quantity of gonadotropins that accelerates sex organ growth, about the same time, the rise in the length of the day reduces the amount of melatonin and reduce inhibition on the stimulating axis. Increased photoperiod increases the sexual maturity of chicks due to stimulation of gonadotropin and sex hormone secretion with subsequent increase in output (8). LEDs are one of the most energyefficient light supplies and can be produced to provide 
certain and stable spectral performance (9), and are absolutely dimmable (10). The birds possess fully advanced visual systems and most of their behaviors are regulated by their vision (11). The lighting is a main factor in bird development, whose function is to stimulate the development of the bird's reproductive system and locomotive activity to higher food and water intakes (12).

Several studies were carried out to investigate the effect of different light intensities on the efficiency of quail growth and reproductive system, but still the lack of knowledge regarding the light impact on quail results, perhaps the aim of the current study is to investigate the influence of various light strength intensity applications on reproduction and growth of male quail.

\section{Materials and methods}

\section{Birds}

The study was Performed at the animal house of the College of Veterinary Medicine, University of Mosul, Iraq during spring season. A total of 80 one-day Japanese quails have been ordered from the Ebaa Research Center, Ministry of Agriculture. Quails were randomly assigned to four groups, 20 birds each group, where four treatments were administered with 4 replicates. The quails were housed in vertically and horizontally isolated floor pens in order to prevent interference and reflection of the various light sources and the room temperature ranged from $20^{\circ} \mathrm{C}$ to $27^{\circ} \mathrm{C}$. The relative humidity ranged from 45 to $60 \%$. During the rearing and development cycles 8 weeks, clean drinking water ad libitum, basal diet ingredient was supplied according to National Research Council (NRC) recommendation (13).

A lighting system of 5 hours of artificial light for 5 days/week has been used. According to the procedure, each space provided the amount of light. The intensity of light available at the top of the bird's head was measured using a digital light meter in various parts of the cages to create a photometric Lux sensor at the head level (14).

\section{Experimental design}

The research was conducted during the spring season. Quails were separated into 4 groups: G1, control group were introduced to normal lightening cycle $12 \mathrm{~h}$ light $: 12 \mathrm{~h}$ dark. G2 quails dark group were exposed to 0.6 Lux, while G3 and G4 were exposed to 45 and 25 Lux respectively. G3 and G4 were exposed to different light intensity for 5 hours daily from 9:00 a.m. to 2:00 p.m. 5 days/week for 8 weeks starting at 14 days of age.

\section{Internal organ weights}

Birds were sacrificed just at the end of the experiment. Visceral organs, including (the heart, liver, gizzard, chest muscle, and testis) and foam material from foam gland were weighted (Weighed and recorded as organ weight/100 g body weight) (15).

\section{Gonadosomatic index (GI)}

Determined by the following equation GSI $=[\mathrm{gonad}$ weight / body total tissue weight] $\times 100$ (16) .

\section{Growth performance parameter}

The initial body weight, final body weight, and total feed intake/quail and food conversion ratio (FCR) were recorded weekly, and the foam material from the cloacal glands weight was recorded (17). Foam obtained by each group of birds was collected and its weight was immediately calculated using a digital analytical balance (18).

\section{Blood sampling}

Blood samples were collected during slaughter and divided into two parts: one to obtain serum separated by blood centrifugation for $15 \mathrm{~min}$ at $3000 \mathrm{rpm}$. Serum samples were kept at $-20^{\circ} \mathrm{C}$ until estimation of triiodothyronine (T3) hormone concentration (VEDA. LAB France Patch number 27088-08) using the spectrophotometer dry cassette. While blood with anticoagulant was used for complete blood constituents including RBCs and WBCs using Natt and Herrick solution (19), PCV, Hb, MCV, MCH, MCHC, differential leukocytic count (DLC) and stress index using Wright stain $(20,21)$.

\section{Sperm parameters}

Semen was taken immediately after the decapitation of the bird by a slight pressure on the ductus deferens from the epididymis ductus to the base of the duct phallus. After that semen diluted with normal physiological saline and spermatogenesis parameters was done including number, live, dead and abnormal sperms (22).

\section{Statistical analysis}

Data was analyzed by means of a one-way analysis of variance (ANOVA). The significance of variations among means was assessed by using the Duncan Multiple Range Test at $\mathrm{P}<0.05$ (23).

\section{Results}

Table 1 showed that the application of 0.6 lux, 45 Lux and 25 Lux light intensity for 5 hours a day created a significant increase in heart weight compared to the control group. 0.6 Lux light program application caused significant decrease in body weight as compared to other groups. 25 Lux exposure causes a significant increase in liver weight associated with 0.6 lux.

There is no significant change in gizzard weight among the groups. Application to 0.6 Lux significantly raises the chest weights as compared to the other light program groups. 
Table 1: Impact of various artificial light levels of intensity on male quail's body weight and relative organs weight

\begin{tabular}{lccccc}
\hline \multirow{2}{*}{ Treatment } & \multicolumn{5}{c}{ Mean $(\mathrm{g} / 100 \mathrm{~g} . \mathrm{bw}) \pm \mathrm{SE}$} \\
\cline { 2 - 6 } & body weight $(\mathrm{g})$ & Heart weight & Liver weight & Gizzard & Chest weight \\
\hline Control & $216.2 \pm 5.54 \mathrm{a}$ & $0.77 \pm 0.02 \mathrm{c}$ & $1.62 \pm 0.02 \mathrm{ab}$ & $1.26 \pm 0.02 \mathrm{a}$ & $21.24 \pm 0.3 \mathrm{ab}$ \\
$0.6 \mathrm{Lux}$ & $191 \pm 3.96 \mathrm{~b}$ & $0.90 \pm 0.05 \mathrm{~b}$ & $1.42 \pm 0.08 \mathrm{~b}$ & $1.49 \pm 0.20 \mathrm{a}$ & $22.11 \pm 0.23 \mathrm{a}$ \\
45 Lux & $214 \pm 5.56 \mathrm{a}$ & $1.07 \pm 0.02 \mathrm{a}$ & $1.75 \pm 0.02 \mathrm{ab}$ & $1.60 \pm 0.02 \mathrm{a}$ & $20.44 \pm 0.21 \mathrm{~b}$ \\
25 Lux & $220.8 \pm 3.4 \mathrm{a}$ & $1.07 \pm 0.01 \mathrm{a}$ & $1.80 \pm 0.21 \mathrm{a}$ & $1.59 \pm 0.09 \mathrm{a}$ & $20.63 \pm 0.41 \mathrm{~b}$ \\
\hline
\end{tabular}

Values shown as mean \pm SE. Small different letters in the column denote significantly at $\mathrm{P}<0.05$ between groups.

Attempting to apply male quail to 0.6 Lux resulted in a significant decline in the weight of the left testis in comparison with other groups; Whereas the weight of the left testis did not change significantly when applied to 45 Lux and 25 Lux according to the control value. No significant change between groups in the weight of the right testis. The data did not indicate any significant change in the gonadosomatic index between control, 0.6 Lux and 25 Lux. Furthermore 45 Lux exposure resulted in a significant increase in the gonadosomatic index associated with 0.6 Lux and 25 Lux. Exposure to Lux 0.6 caused a significant reduction in the weight of the foam material from the foam gland compared to other groups, there was non-significant differences in the weight of foam material between control, 45 Lux and 25 Lux as compared between each other's. whereas 0.6 Lux caused significant decrease in foam weight as compared with other groups (Table 2).

Table 3 revealed that exposure to 0.6 Lux resulted in a significant reduction in sperm count and live sperm count, with a significant increase in dead sperm compared to control group, whereas there were no significant changes in sperm count, live sperm count and dead sperm count when applied to 45 Lux and 25 Lux compared to control. No significant difference between groups in abnormal sperm counts and triiodothyronine hormone level.
The current study showed no significant changes in the RBC count for 0.6 Lux, 45 Lux and 25 Lux compared to the control group. Application for 25 Lux causes a significant increase in RBC counts compared to 0.6 Lux. There is no significant difference between groups in the WBC count exposure to 45 Lux and 25 Lux caused significant increase in PCV value compared to the control group, while exposure to $0.6 \mathrm{Lux}$ caused significant decrease in PCV value compared with other groups. Applying to 45 Lux and 25 Lux results in a significant increase in hemoglobin concentrations compared with 0.6 Lux and control groups (Table 4).

Table 5 showed no variation between groups in the erythrocyte index except for 45 Lux and 25 Lux program exposures, which resulted in a significant increase in the mean hemoglobin concentration compared to 0.6 Lux and the control value.

The result clarified in table 6 applies to program 0.6 Lux, caused significant decrease in the percentage of lymphocytes accompanied with a significant increase in the percentage of heterophils as compared to other groups. No significant changes between groups in the percentage of basophilic or eosinophilic. There is a significant increase in the monocyte percentage and stress index for 0.6 Lux relative to other groups.

Table 2: Impact of various artificial light levels of intensity on male quail's sex relative organs weight

\begin{tabular}{lcccc}
\hline \multirow{2}{*}{ Treatment } & \multicolumn{4}{c}{ Mean \pm SE } \\
\cline { 2 - 5 } & Left testis weight & Right testis weight & Gonadosomatic index & Foam weight \\
\hline Control & $1.67 \pm 0.04 \mathrm{ab}$ & $1.57 \pm 0.09 \mathrm{a}$ & $1.50 \pm 0.05 \mathrm{ab}$ & $0.026 \pm 0.002 \mathrm{a}$ \\
0.6 Lux & $1.20 \pm 0.03 \mathrm{c}$ & $1.34 \pm 0.14 \mathrm{a}$ & $1.33 \pm 0.11 \mathrm{~b}$ & $0.012 \pm 0.002 \mathrm{~b}$ \\
45 Lux & $1.89 \pm 0.14 \mathrm{a}$ & $1.69 \pm 0.11 \mathrm{a}$ & $1.66 \pm 0.11 \mathrm{a}$ & $0.024 \pm 0.002 \mathrm{a}$ \\
25 Lux & $1.51 \pm 0.07 \mathrm{~b}$ & $1.50 \pm 0.07 \mathrm{a}$ & $1.36 \pm 0.06 \mathrm{~b}$ & $0.030 \pm 0.003 \mathrm{a}$ \\
\hline
\end{tabular}

Values shown as means \pm SE. Small different letters in the column denote significantly at $\mathrm{P}<0.05$ between groups.

Table 3: Impact of artificial light levels of intensity on male quail's spermatogenesis and triiodothyronine hormone level

\begin{tabular}{lccccc}
\hline \multirow{2}{*}{ Treatment } & \multicolumn{5}{c}{ Mean \pm SE } \\
\cline { 2 - 6 } & Sperm count $10^{6} / \mathrm{mm}^{3}$ & Live sperm \% & Dead sperm \% & Abnormal sperm \% & Triiodothyronine (ng/ml) \\
\hline Control & $2.15 \pm 0.14 \mathrm{a}$ & $75.60 \pm 2.94 \mathrm{a}$ & $24.40 \pm 2.94 \mathrm{~b}$ & $3.80 \pm 0.96 \mathrm{a}$ & $0.88 \pm 0.17 \mathrm{a}$ \\
$0.6 \mathrm{Lux}$ & $1.32 \pm 0.13 \mathrm{~b}$ & $52.80 \pm 8.23 \mathrm{~b}$ & $47.20 \pm 8.23 \mathrm{a}$ & $5.20 \pm 1.46 \mathrm{a}$ & $1.22 \pm 0.38 \mathrm{a}$ \\
$45 \mathrm{Lux}$ & $2.48 \pm 0.16 \mathrm{a}$ & $78.00 \pm 3.49 \mathrm{a}$ & $22.00 \pm 3.49 \mathrm{~b}$ & $3.204 \pm 0.80 \mathrm{a}$ & $0.90 \pm 0.77 \mathrm{a}$ \\
25 Lux & $2.46 \pm 0.13 \mathrm{a}$ & $78.00 \pm 3.88 \mathrm{a}$ & $21.60 \pm 3.88 \mathrm{~b}$ & $2.80 \pm 0.58 \mathrm{a}$ & $0.94 \pm 0.08 \mathrm{a}$
\end{tabular}

Values shown as means \pm SE. Small different letters in the column denote significantly at $\mathrm{P}<0.05$ between groups. 
Iraqi Journal of Veterinary Sciences, Vol. 35, No. 4, 2021 (679-685)

Table 4: Impact of various artificial light levels of intensity on male quail's blood constituent

\begin{tabular}{lcccc}
\hline \multirow{2}{*}{ Treatment } & \multicolumn{4}{c}{ Mean \pm SE } \\
\cline { 2 - 5 } & $\mathrm{RBC} \times 10^{6} / \mathrm{mm}^{3}$ & $\mathrm{WBC} \times 10^{3} / \mathrm{mm}^{3}$ & $\mathrm{PCV} \%$ & $\mathrm{Hb} / 100 \mathrm{ml}$ \\
\hline Control & $3.60 \pm 0.16 \mathrm{ab}$ & $3.43 \pm 0.40 \mathrm{a}$ & $50.80 \pm 0.48 \mathrm{~b}$ & $9.67 \pm 0.31 \mathrm{c}$ \\
$0.6 \mathrm{Lux}$ & $2.83 \pm 0.27 \mathrm{~b}$ & $4.11 \pm 0.21 \mathrm{a}$ & $43.40 \pm 1.02 \mathrm{c}$ & $9.18 \pm 0.17 \mathrm{c}$ \\
45 Lux & $3.60 \pm 0.24 \mathrm{ab}$ & $4.18 \pm 0.12 \mathrm{a}$ & $58.40 \pm 0.74 \mathrm{a}$ & $10.79 \pm 0.16 \mathrm{~b}$ \\
25 Lux & $4.22 \pm 0.28 \mathrm{a}$ & $3.70 \pm 0.29 \mathrm{a}$ & $60.60 \pm 1.16 \mathrm{a}$ & $13.19 \pm 0.59 \mathrm{a}$ \\
\hline
\end{tabular}

Values shown as means \pm SE. Small different letters in the column denote significantly at $\mathrm{P}<0.05$ between groups.

Table 5: Impact of various artificial light levels of intensity on male quail's erythrocyte indices

\begin{tabular}{lccc}
\hline \multirow{2}{*}{ Treatment } & & Mean \pm SE & \\
\cline { 2 - 4 } & MCV fl & MCH pg & MCHC g/100ml \\
\hline Control & $142.11 \pm 5.63 \mathrm{a}$ & $26.98 \pm 6.44 \mathrm{a}$ & $18.42 \pm 0.80 \mathrm{~b}$ \\
0.6 Lux & $158.04 \pm 13.19 \mathrm{a}$ & $30.64 \pm 2.61 \mathrm{a}$ & $18.51 \pm 0.49 \mathrm{~b}$ \\
45 Lux & $165.71 \pm 13.56 \mathrm{a}$ & $31.87 \pm 2.52 \mathrm{a}$ & $21.08 \pm 0.11 \mathrm{a}$ \\
$25 \mathrm{Lux}$ & $145.18 \pm 6.93 \mathrm{a}$ & $33.40 \pm 2.87 \mathrm{a}$ & $21.82 \pm 1.22 \mathrm{a}$ \\
\hline
\end{tabular}

Values shown as means \pm SE. Small different letters in the column denote significantly at $\mathrm{P}<0.05$ between groups.

Table 6: Impact of various artificial light levels of intensity on male quail's differential leucocytic count and stress index

\begin{tabular}{lcccccc}
\hline \multirow{2}{*}{ Treatment } & \multicolumn{5}{c}{ Mean \pm SE } \\
\cline { 2 - 7 } & Lymphocyte \% & Heterophils \% & Basophil \% & Eosinophil \% & Monocyte \% & Stress index \\
\hline Control & $69.80 \pm 2.22 \mathrm{a}$ & $18.80 \pm 2.88 \mathrm{~b}$ & $0.40 \pm 0.24 \mathrm{a}$ & $0.60 \pm 0.40 \mathrm{a}$ & $10.40 \pm 1.36 \mathrm{~b}$ & $0.27 \pm 0.05 \mathrm{~b}$ \\
$0.6 \mathrm{Lux}$ & $49.20 \pm 5.41 \mathrm{~b}$ & $27.80 \pm 3.32 \mathrm{a}$ & $0.40 \pm 0.24 \mathrm{a}$ & $0.60 \pm 0.40 \mathrm{a}$ & $22.00 \pm 3.43 \mathrm{a}$ & $0.62 \pm 0.16 \mathrm{a}$ \\
45 Lux & $69.60 \pm 2.20 \mathrm{a}$ & $18.40 \pm 3.32 \mathrm{~b}$ & $0.40 \pm 0.24 \mathrm{a}$ & $0.40 \pm 0.40 \mathrm{a}$ & $11.20 \pm 1.5 \mathrm{~b}$ & $0.26 \pm 0.05 \mathrm{~b}$ \\
25 Lux & $71.40 \pm 1.43 \mathrm{a}$ & $15.60 \pm 1.46 \mathrm{~b}$ & $0.40 \pm 0.24 \mathrm{a}$ & $0.60 \pm 0.24 \mathrm{a}$ & $12.0 \pm 1.84 \mathrm{~b}$ & $0.21 \pm 0.02 \mathrm{~b}$ \\
\hline
\end{tabular}

Values shown as means \pm SE. Small different letters in the column denote significantly at $\mathrm{P}<0.05$ between groups.

The data in Table 7 do not show a significant variation between groups in the initial weight, final weight and total weight gain. Total feed intake increased significantly in 45 Lux and 25 Lux compared to the control value. Application of light 0.6 Lux causes a significant decrease in total feed intake relative to the other groups. Light intensity did not significantly improve the feed conversion ratio, and 45 Lux worst group affect the feed conversion ratio compared to other groups. However, the best feed conversion ratio was detected in normal daylight then. 0.6 Lux and 25 Lux respectively.

Table 7: Impact of various artificial light levels of intensity on male quail's growth performance

\begin{tabular}{lccccc}
\hline \multirow{2}{*}{ Treatment } & \multicolumn{5}{c}{ Mean \pm SE } \\
\cline { 2 - 6 } & Initial weight & Final weight & Total weight gain & Total feed intake & Feed conversion ratio \\
\hline Control & $60.85 \pm 1.45 \mathrm{a}$ & $170.35 \pm 9.19 \mathrm{a}$ & $109.50 \pm 8.38 \mathrm{a}$ & $347.42 \pm 1.18 \mathrm{~d}$ & $3.23 \pm 0.28 \mathrm{~b}$ \\
0.6 Lux & $63.35 \pm 2.57 \mathrm{a}$ & $172.45 \pm 5.66 \mathrm{a}$ & $109.10 \pm 5.12 \mathrm{a}$ & $376.33 \pm 1.17 \mathrm{c}$ & $3.40 \pm 0.16 \mathrm{~b}$ \\
$45 \mathrm{Lux}$ & $61.70 \pm 1.44 \mathrm{a}$ & $184.70 \pm 5.89 \mathrm{a}$ & $123.00 \pm 7.08 \mathrm{a}$ & $620.05 \pm 0.25 \mathrm{a}$ & $5.08 \pm 0.28 \mathrm{a}$ \\
25 Lux & $63.90 \pm 1.64 \mathrm{a}$ & $182.35 \pm 4.44 \mathrm{a}$ & $118.45 \pm 3.39 \mathrm{a}$ & $449.00 \pm 0.35 \mathrm{~b}$ & $3.80 \pm 0.11 \mathrm{~b}$ \\
\hline
\end{tabular}

Values shown as means \pm SE. Small different letters in the column denote significantly at $\mathrm{P}<0.05$ between groups.

\section{Discussion}

The current study considers 0.6 Lux intensity to be low light intensity or dim, thus low light levels can reduce physical activity leading to more rest and sleep. Blatchford et al. (12) reported that light intensity had a major effect on the growth of broiler chickens. Photoperiods of just fewer than $18 \mathrm{~h}$ have been reported to reduce feed intake (24). The present study found that application to 25 Lux and 45 Lux resulted in a significant increase in breast mass and heart weight. It was also observed previously that breast meat yield increased linearly as the photoperiod rearing treatments increased from 14 light: 10 dark to 23 light: 1 dark (24). Japanese quail photo stimulation with white LEDs is more effective in improving the growth of their organs (25). Yahav et al. (26) documented that light 
strength had an effect on the weight of the heart muscle, but perhaps not on the weight of the breast meat mass, weight of the testis or weight of the abdominal fat as a proportion of the body weight.

The present study showed that the adjustment to 0.6 Lux dark for 5 hours daily resulted in a decrease in testicular weight and foam material weight, as light is the essential component of the atmosphere that governs the numerous physiological functions of birds (1). Non-natural lighting has also been commonly used in the poultry industry in order to improve production and reproductive performance (5). The present findings did not show any significant differences in testes and foam weight when applied to 25 Lux and 45 Lux compared to the control value. This research did not comply with Retes et al. (27), who announced that fluorescent and red LED bulbs had a higher testis weight and a higher quail area of seminiferous tubules at 35 days of age., In addition, fluorescent bulbs have resulted in higher germ epithelium heights at this age, even at 57 days of age, and white LED bulbs have resulted in higher testicular development (27).

Other findings demonstrate that There is a powerful connection between the size of the foam gland and the weight of the testicles; so, the growth of the foam gland could be used as marker of testicular activity (28).

0.6 Lux induced a significant decrease in sperm concentration and live sperm with a large increase in dead sperm, although there were no major improvements in sperm count, live sperm count and dead sperm when applied to 45 Lux and 25 Lux.

Retes et al. (29) suggested that different types of lamps did not affect the sperm efficiency and fertility of male quail sperm. The findings of the current study showed no significant differences in RBC counts for 0.6 Lux, 45 Lux and 25 Lux relative to the control group, whereas 25 Lux exposure induces a large increase in $\mathrm{RBC}$ counts relative to 0.6 Lux.

Exposure to 45 Lux and 25 Lux causes a significant increase in PCV value relative to the control group, whereas exposure to 0.6 Lux causes a significant reduction in PCV value. The result showed no significant difference between groups in the WBC count.

Applying to 45 Lux and 25 Lux result in significant increase in hemoglobin concentrations compared to 0.6 Lux and control groups. Several researchers have described the effect of light on the hematological parameters of some avian and mammals. Olanrewaju et al. (29) concluded that high day exposure to light significantly reduced broiler hematocrit and hemoglobin.

Hassan et al. (30), on the other hand, reported that monochromatic lights had no effect on the duck hematocrit but did not indicate the period of exposure to light. Dedeke et al. (31) confirmed that tolerance to artificial white light had a significantly lower PCV percent value, also the eosinophil was also significantly higher under yellow light and significantly lowered under control.
There is scientific evidence that various light systems can cause either physiological or psychological stress responses heterophil/lymphocyte broiler ratios have been noted to be unaffected photoperiod (32). The heterophil / lymphocyte ratio is often used as a stress marker in birds (33).

Pervious analysis, documented that $\mathrm{H} / \mathrm{L}$ ratio of both male and female was found to be higher in the continuous light category. On the other hand, just the variance among male quails was originate to be significant.

Similarly, Moore and Siopes (34) achieved that the H/L ratio was the maximum in continuously light - filled quails. Therefore, the commonly used continuous light system is thought to trigger stress in male quails.

Likewise, Moore and Siopes (34) noticed that the H/L ratio was the maximum for continuously lit quails. Throughout the earlier findings, during which two lighting systems continuous light and 14 light: 10 dark were compared, it was evaluated that the number of heterophils increased and the number of lymphocytes decreased, indicating that chickens were stressed due to the continuous lighting (35).

Furthermore, the larger maximum standard error values for heterophils, lymphocytes and $\mathrm{H} / \mathrm{L}$ ratio in quails suggest the presence of a wide range individual variation as the lighting program increase that the need for darkness. The data did not indicate a significant difference between the groups in which the quail resistance varies from the artificial light intensity to the initial weight, final weight and total weight gain.

Application of light 0.6 Lux induces a significant decrease in average feed intake compared to other categories. Total feed intake significantly increased in 45 Lux and 25 Lux compared to the control value. Light strength did not significantly improve the feed conversion ratio, and 45 Lux is the worst group affect the feed conversion ratio compared to other groups. However, the best feed conversion ratio was observed in normal daylight, 0.6 Lux and 25 Lux.

Further experimental work has shown that light intensity ranging from 1 to 151 Lux does not affect body weight, feed intake and feed conversion in broiler chickens (36).

Other research indicates that artificial light has beneficial economic effects on quail results. The current study revealed that reaction to different light intensities did not influence the level of triiodothyronine hormone level relative to the control group, this result disagrees with pervious study (37) who found that light induces increased releasing of metabolic hormones, including triiodothyronine, thyroxine, insulin, growth hormone and insulin like growth factor-1.

These hormones have been involved in the growth and enhancement of quail and domestic birds' competitive and reproductive functions. 


\section{Conclusion}

The white light intensity affected the study criteria differently, as 0.6 Lux negatively affected the reproductive characteristics as well as the percentage of lymphocytes and heterophil and stress index. While 45, 25 Lux had positive effects on the constituent blood of Male quail.

\section{Acknowledgements}

The reviewers wanted to express their sincere gratitude to the Scientific Committee of the Department of Physiology, Biochemistry and Pharmacology at the College of Veterinary Medicine. We extend our deepest thanks to the members of the experimental laboratory animal research unit.

\section{Conflict of interest}

The authors declare that there is no conflict of interest

\section{References}

1. Deep A, Schwean LK, Crowe TG, Fancher BI, Classen HL. Effect of light intensity on broiler behavior and diurnal rhythms. Appl Anim Behav Sci. 2012;136(1):50-6. DOI: 10.1016/j.applanim.2011.11.002

2. Parvin R, Mushtaq MM, Kim MJ, Choi HC. Light emitting diode (LED) as a source of monochromatic light: A novel lighting approach for behavior, physiology and welfare of poultry. World's Poult Sci J. 2014;70(3):543-56. DOI: 10.1017/S0043933914000592

3. Lewis PD, Danisman R, Gous RM. Photoperiodic responses of broilers: Growth, feeding behavior, breast meat yield and testicular growth. Brit Poult Sci. 2009;50:657-666. DOI: 10.1080/00071660903338452

4. Gongruttananun N. Influence of red light on reproductive performance, eggshell ultrastructure, and eye morphology in Thainative hens. Poult Sci. 2011;90(12):2855-63. DOI: 10.3382/ps.201101652

5. Min JK, Hossan MS, Nazma A, Jae CN, Han TB, Hwan KK, Dong WK, Hyun SC, Hee CC, Ok SS. Effect of monochromatic light on sexual maturity, production performance and egg quality of laying hens. Avi Biol Res. 2012;5(2):69-74. DOI: 10.3184\%2F175815512X13350270679453

6. Deep A, Schwean LK, Crowe TG, Fancher BI, Classen HL. Effect of light intensity on broiler production, processing characteristics, and welfare. Poult Sci. 2010;89(11):2326-33. DOI: 10.3382/ps.201000964

7. Kumar V, Rani S. Light sensitivity of the photoperiodic response system in higher vertebrates: Wavelength and intensity effects. Indian J Exp Biol. 1999;11:1053-64. https://pubmed.ncbi.nlm.nih.gov/10783735/

8. Bedecarrats GY, Mcfarlane H, Maddineni SR, Ramachandran R. Gonadotropin-inhibitory hormone receptor signaling and its impact on reproduction in chickens. General Comp Endocrinol. 2009;163:7-11. DOI: 10.1016/j.ygcen.2009.03.010

9. Steranka FM, Bhat J, Collins D, Cook L, Craford MG, Fletcher R, Gardner N, Grillot P, Goetz W, Keuper M, Khare R, Kim A, Krames M, Harbers G, Ludowise M, Martin PS, Misra M, Mueller G, Mueller MR, Rudaz S, Shen YC, Steigerwald D, Stockman S, Subramanya S, Trotter T, Wierer JJ. High power LEDs - Technology status and market applications. Physica Status Solid Appl Res. 2002;194:380388. DOI: 10.1002/1521-396X(200212)194:2\%3C380

10. Benson ER, Hougentogler DP, McGurkn J, Herrman E and Alphin RL. Durability of incandescent, compact fluorescent, and light emitting diode lamps in poultry conditions. Appl Eng Agricult. 2013;29:103-111. DOI: 10.13031/2013.42531

11. Mendes AS, Paixão SJ, Restelatto R, Morello GM, Jorge de Moura D, Possenti JC. Performance and preference of broiler chickens exposed to different lighting sources. J Appl Poult Res. 2013;22(1):62-70. DOI: 10.3382 /japr.2012-00580

12. Blatchford RA, Klasing KC, Shivaprasad HL, Wakenell PS, Archer GS, Mench JA. The effect of light intensity on the behavior, eye and leg health, and immune function of broiler chickens. Poult Sci. 2009;88(1):20-8. DOI: 10.3382/ps.2008-00177

13. National Research Council (NRC). Nutrient requirement of poultry. $9^{\text {th }}$ ed. Washington: National Academy press; 1994. DOI: www.doi.org/10.1093/japr/3.1101

14. Lewis PD, Morris TR. Responses of domestic poultry to various light sources. World's Poult Sci J. 1998;54(1):7-25. DOI: 10.1079/WPS19980002

15. Matty HN, Hassan AA. Effect of supplementation of encapsulated organic acid and essential oil Gallant $+\circledR$ on some physiological parameters of Japanese quails. Iraqi J Vet Sci. 2020;34(1):181-188. DOI: 10.33899/ijvs.2019.125732.1142

16. Orlu EE, Egbunike GN. Breed and seasonal variations in the testicular morphometry, gonadal and extragonadal sperm reserves of the barred Plymouth rock and Nigerian indigenous breeds of the domestic fowl. $\begin{array}{llll}\text { Pakistan J Biol Sci. 2010;13(3):120-5. } & \text { DOI: }\end{array}$ 10.3923/pjbs.2010.120.125.

17. Hameed HM, Aga FK, Abdulrahman SY. Effect of $\beta$-mannanase, Lysolecithin and probiotic on some reproductive performance and hormone profile in female quail. Iraqi J Vet Sci. 2020;34(1):87-93. DOI: 10.33899 /ijvs.2019.125587.1097

18. Mohan J, Moudgal RP, Sastry KV, Tyagi J, Singh R. Effects of hemicastration and castration on foam production and its relationship with fertility in male Japanese quail. Theriogenol. 2002;58(1):29-39. DOI: 10.1016/S0093-691X(02)00863-4

19. Abdul-Majeed AF, Abdul-Rahman SY. Impact of breed, sex and age on hematological and biochemical parameters of local quail. Iraqi J Vet Sci. 2021;35(3):459-464. DOI: 10.33899/ijvs.2020.126960.1432

20. Hassan AA, Asim RA. Effect of vitamin C and acetylsalicylic acid supplementation on some hematological value, heat shock protein 70 concentration and growth hormone level in broiler exposed to heat stress. Iraqi J Vet Sci. 2020;34(2):357-363. DOI: 10.33899/ijvs.2019.125950.1195

21. Campbell T W. Avian hematology and cytology. Iowa: Iowa State University Press; 1988. 101 p. [available at]

22. Mamun Tarif AM, Bhuiyan MMU, Ferdousy RN, Juyena NS, Mollah MBR. Evaluation of semen quality among four chicken lines. IOSR J Agricul Vet Sci. 2013;6(5):07-13. DOI: 10.9790/2380-0650713

23. Steel R GD, Torrie JH, Dickey DA. Principles and procedures of statistics: A Biometrical Approach. $3^{\text {rd }}$ ed. New York: McGraw-Hill Book Co; 1997. 350-386 p. DOI: 10.4236/blr.2014.5424

24. Ines Rodrigues and Mingan Choct. Feed intake pattern of broiler chickens under intermittent lighting: Do birds eat in the dark?. Anim Nutr. 2019;5(2):174-178. DOI: www.doi.org/10.1016/j.aninu.2018.12.002

25. Bobadilla MF, Canas-Mendoza EA, Batista LM, Retes PL, Ferreira LG, Alcebiades SA, Teixeira LV, Alvarenga RR, Fassani EJ, Zangeronimo MG. Influence of light sources on body characteristics of female Japanese quail (Coturnix coturnix japonica) in different reproductive ages. Anim Prod Sci. 2019;59(3):427-34. DOI: 10.1071/an16652

26. Yahav S, Hurwitz S, Rozenboim I. The effect of light intensity on growth and development of turkey toms. Brit Poult Sci. 2000;41(1):101-6. DOI: 10.1080/00071660086484

27. Retes PL, Esposito M, das Neves DG, Viana AG, Coelho LM, Bobadilla MF, Alvarenga RR, Fassani EJ, Peixoto JV, Zangeronimo MG. Influence of different types of lamps on the reproductive development of male Japanese quail (Coturnix coturnix japonica). Theriogenol. 2017;94:59-63.

DOI: 10.1016/j.theriogenology.2017.02.011

28. Reshag AF, Abood DA, Ahmed MA. The effects of waste products of generators exhausts on foam gland in male Japanese quail (Contunix 
conurnix) anatomical and histological study. Kufa J Vet Med Sci. 2011;2(2):11-8. [available at]

29. Olanrewaju HA, Purswell JL, Collier SD, Branton SL. Interactive effects of photoperiod and light intensity on blood physiological and biochemical reactions of broilers grown to heavy weights. Poult Sci. 2013;92:1029-1039. DOI: $10.3382 / p s .2012-02792$

30. Hassan RM, Shabiha S, Kyeong SR. Effect of various monochromatic LED light colors on performance, blood properties, bone mineral density, and meat fatty acid composition of ducks. J Poult Sci. 2017;54:66-72. DOI: $10.2141 /$ jpsa.0160012

31. Dedeke GA, Kehinde FO, Olatinwo OR, Johnson OI, Adewale AO. Exposure of albino rats (Rattus norvegicus) to lights of varying wavelengths: Effect on hematological profile, plasma electrolytes and weight gain. Zool. 2017;15:29-34. [available at]

32. Blai RR, Newberry C, Gardiner EE. Effects of lighting pattern and dietary tryptophan supplementation on growth and mortality in broilers. Poult Sci. 1993;72:495-502. DOI: 10.3382/ps.0720495

33. Onbasilar EE, Erol H, Cantekin Z, Kaya U. Influence of intermittent lighting on broiler performance, incidence of tibial dyschondroplasia, tonic immobility, some blood parameters and antibody production. Asian-Aust J Anim Sci. 2007;20(4):550-555. DOI: 10.5713/ajas.2007.550

34. Moore CB, Siopes TD. Effects of lighting conditions and melatonin supplementation on the cellular and humoral immune responses in Japanese quail Coturnix coturnix japonica. Gen Comp Endocr. 2000;1(19):95-104. DOI: 10.1006/gcen.2000.7496

35. Campo JL, Gil MG, Davila SD, Munoz I. Effect of lighting stress on fluctuating asymmetry heterophil to lymphocyte ration, and tonic immobility duration in eleven breeds of chickens. Poult Sci. 2007;86(1):37-45. DOI: $10.1093 / \mathrm{ps} / 86.1 .37$

36. Lien RJ, Hess JB, McKee SR, Bilgili SF, Townsend JC. Effect of light intensity and photoperiod on live performance, heterophil to lymphocyte ratio, and processing yields of broilers. Poult Sci. 2007;86(7):1287-93. DOI: $10.1093 / \mathrm{ps} / 86.7 .1287$

37. Khalil HA, Hanafy AM, Hamdy AM. Effect of artificial and natural day light intensities on some behavioral activities, plumage conditions, productive and physiological changes for Japanese quail. Asian J Poult Sci. 2016;10:52-63. DOI: 10.3923/ajpsaj.2016.52.63

\section{أثر شدة الإضاءة المختلفة في بعض أوجه الأداء

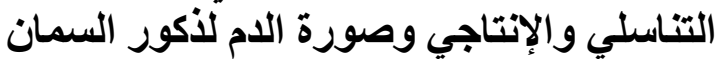 هيام نذير متي، سهى محمود أحمد و أشواق احمد حسن}

الموعل، الفسلجة والكيمياء الحياتية والأدوية، كلية الطب البيطري، جامعة

الخلاصة

صمدت الدراسة الحالية لمعرفة تأثير شدة الضوء الأبيض على الثى

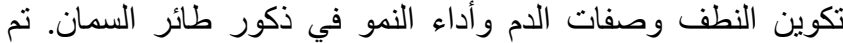

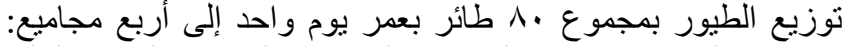
مجموعة السيطرة عرضت للإضـاءة الطبيعية و المجاميع الثانية و الثالثة

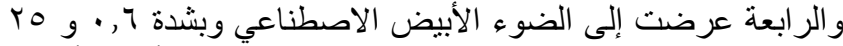

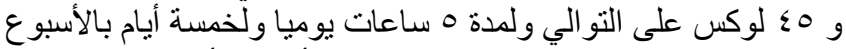

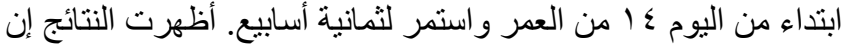

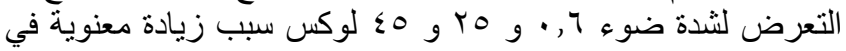

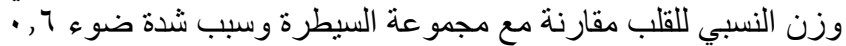

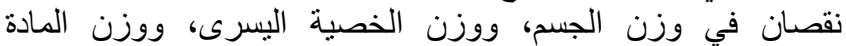

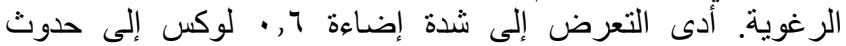
انخفاض معنوي في عد النطف، والنطف الحية وزية وزيادة بالنطف النفاء الميتة.

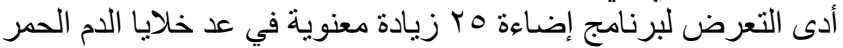

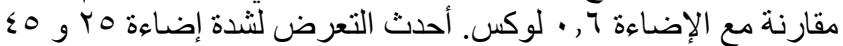

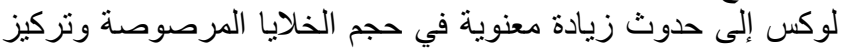

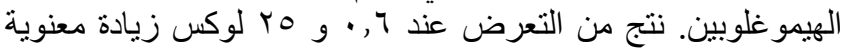

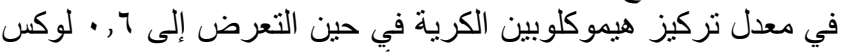

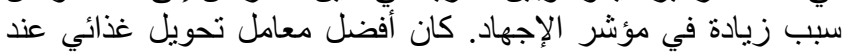

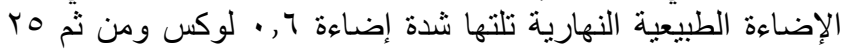

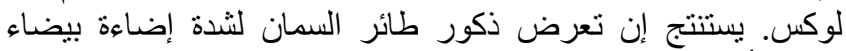
مختلفة أثر في بعض المعايير الفسلجية و التكاثرية. 